\title{
Law Enforcement Proxies Matter for the Law and Finance Nexus
}

\author{
Valentin Z. Toçi ${ }^{\mathrm{a}}$, Iraj Hashi ${ }^{\mathrm{b}}$ \\ ${ }^{a}$ University of Prishtina, Fakulteti Ekonomik pn, Prishtina, 10000, Republic of Kosovo \\ ${ }^{b}$ Staffordshire University, Leek Road, Stoke on Trent, ST4 2DF, United Kingdom
}

\begin{abstract}
The paper employs various measures of law enforcement to provide new evidence on the importance of legal institutions for different dimensions of financial development in transition economies. It offers a critical assessment of law enforcement measures employed in recent studies by showing that some proxies for law enforcement in the credit market may not be appropriate. Hence, care should be taken in how the quality of institutions is measured and the context which it represents. An original approach to measuring law enforcement in the credit market is developed by embodying the legal theory of dispute resolution and assessing this approach by collecting primary data for Kosovo. The findings suggest that Kosovo compares well with countries in the region and other transition economies in terms of the enforcement of creditor rights.
\end{abstract}

Keywords: Law Enforcement; Financial Development; Transition Economies; Kosovo

\section{(C) 2013 Published by SSBFNET}

\section{Introduction}

The idea that the financial development spurs economic growth has a long heritage and the overwhelming majority of theoretical and empirical work points to the direction that finance facilitates economic growth (Goldsmith, 1969; King and Levine, 1993; Levine, 1997; Beck, et al., 1999; Levine, et al., 2000). However, as Zingales (2003) points out, it is of little use to know that the relation between finance and growth exists if policymakers do not know how to promote financial development. Therefore, an important question is what shapes the development of the financial system? The aim of this paper is to respond to this question by examining the role of institutions in financial development in transition economies. Credit markets are generally considered as underdeveloped in transition economies, with credit rationing as the main consequence. Information asymmetries and transaction costs create credit market imperfections which may lead to credit rationing (Stiglitz and Weiss, 1981). To correct for this, collateral plays an important role (Bester, 1985, 1987). However, the efficiency of using collateral and other restrictive covenants are closely related to the working of institutions such as the legal system and the judiciary that support the creditors' right to repossess collateral and ensure compliance with contractual agreements (LaPorta et al., 1997, 1998; DeSoto, 2000). Hence, by establishing and enforcing the legal provisions on creditor rights, the legal institutions influence the incentives of creditors to lend more and on better terms, and may mitigate the common problems of the credit market such as moral hazard and adverse selection and contribute to the development of the financial system.

LaPorta et al. (1997) using a sample of 39 countries around the world, found that countries with poorer protection of creditor rights, measured by the character of legal rules and the quality of law enforcement, have narrower debt

${ }^{\text {a }}$ Corresponding author. Valentin Z. Toçi, Tel.: +377 44376907. 
markets. More recently Djankov, et al. (2007) have extended LaPorta et al.'s cross-section analysis to 129 countries around the world. They found that higher creditor rights protection through the legal system and the presence of information sharing institutions are related to deeper debt markets. In the transition context, Slavova (1999) used a cross-country study of 21 transition economies in 1998 and found that only legal enforcement matters for banks' credit to the private sector, and that the law on books itself does not affect the banking sector intermediation. Similarly, Pistor, et al. (2000) find a significant correlation between the law enforcement variables and the development of credit markets in transition economies. Nevertheless, in these studies when macroeconomic stability measures are introduced their models the significance of law enforcement variable disappears.

In this paper the evidence is provided to show that the enforcement of creditor rights, rather than the quality of the law itself, has an impact on financial development; and that enforcement of collateral laws, rather than bankruptcy laws, is the main channel through which law contributes to financial development in transition economies. Unlike other studies, a broad set of measures such as the depth of the credit market, the distinction between credit to the household and corporate sector, the quality of credits, and terms of lending are employed in order to capture different dimensions of financial development. In addition, it is shown that the empirical outcomes are sensitive to different proxies for law enforcement. The performance of institutions in general and that of the law enforcement in particular are difficult to measure. However, much progress has been achieved recently in this direction. Various methods have been developed to measure the quality of law enforcement and have been used in the empirical work investigating the importance of the legal reform for the functioning of financial markets. This paper offers a critical assessment of measures employed in recent studies by showing that the use of different proxies for law enforcement in the credit market produces different results and that not all measures may be appropriate.

After the war in 1999, Kosovo started building the institutions needed for the functioning of a market economy from scratch. In terms of the functioning of the financial market and the protection of creditor rights, there is a general agreement that institutions are already in place and the relevant laws are already on the statute book. In terms of enforcement, however, there is no conclusive evidence on how these laws work in practice as different studies provide different assessments. Some point to the weak rule of law in the country in general and the enforcement of creditor rights in particular. Others highlight the strong protection of creditor rights - better than in many transition economies and even some high-income countries. This paper applies the EBRD's methodology for measuring the enforcement of collateral laws in order to generate results for Kosovo comparable to those of other transition countries. The EBRD methodology has been extended by encompassing several stages of dispute resolution such as harm, bargaining, the assertion of the legal claim and trial, and by collecting primary data. Findings suggest that Kosovo compares well with other transition economies in terms of the enforcement of creditor rights.

\section{Measuring The Quality of Institutions: A Critical Assessment}

The first index showing the creditor rights as they appear in books of law was compiled by LaPorta, et al. (1997). By using bankruptcy laws as a proxy for measuring creditor rights, they used a scoring system ranging from 0 (worst) to 4 (best) to evaluate the extent of creditor protection as they appear 'on the books' on the basis of whether particular features were present in the law protecting creditor rights. This indicator has been extended over time, e.g. Pistor (2000), and now the most widely used measure of creditor rights protection is the World Bank 'doing business' methodology extended to ten characteristics that are present in laws and considered as enhancing creditor rights. Regarding enforcement of creditor rights, LaPorta, et al. (1997) measured the degree of law enforcement in different countries using several indicators. For example, the authors used the Rule of Law Index which was an assessment of the law and order tradition in the country produced by a private rating agency. To proxy for law enforcement, they also used the degree of corruption in the government, risk of expropriation and contract repudiation by the government, etc. On the other hand, the EBRD has been publishing indicators of institutional development in transition economies since 1995. The EBRD has concentrated on identifying the extent to which the laws, as they appear on the books, comply with international standards (extensiveness) and to what extent law enforcement (effectiveness) has been improving in transition economies. In the Legal Indicator Survey (LIS), EBRD provides a ranking ranging from 1 (little or no progress in reform) to 4+ (standard of advanced market economies) for both extensiveness and effectiveness of laws. These rankings are based on the surveys of local lawyers and experts regarding the financial institution regulations covered under LIS on Financial Institutions and the commercial laws (bankruptcy laws, company laws and secured transactions laws) covered under LIS on Commercial Activities. 
Among the most widely used indicators of institutional quality is the World Bank a composite index for rule of law (RLI) ranging from -2.5 to 2.5 (higher scores corresponding to better law enforcement) as a part of six 'governance indicators'. It combines variables from 24 sources such as private risk assessment agencies, public institutions, international financial institutions, household and firm surveys. Although it embodies some characteristics related to the efficiency of contract enforcement such as the enforceability of private contracts, and the speediness of judicial process, it contains diversity of other dimensions such as kidnapping of foreigners, organized crime, civil liberties, the freedom of press, political rights, etc. Although these measures may be good proxies for law enforcement in the particular country, they are a mixture of indicators and reflect the general institutional setting. In some cases the variable captures the legal and non-legal features of society and, in other cases, it aggregates the effects of a large number of legal institutions (Davis, 2004). Being multidimensional, none of these deals explicitly with law enforcement in the lender-borrower relationship. Arner, et al. (2006) point out that one of the main weaknesses of the law and finance school is the usefulness in terms of the scope such measures provide for legal or regulatory reform given that the legal related variables have been too general. Hence, from a policy perspective it may be of little use to know that more rule of law is needed. Rather, identifying specific dimensions of the law that can be modified in a specific market and the institutional bodies responsible for the implementation may give clearer view of specific reforms that are needed. For policymakers dealing with the financial sector reform it is more important to know, for example, that the deficiencies are primarily related to the enforcement of collateral law rather than bankruptcy law.

In the transition context Slavova (1999) uses the EBRD measure of extensiveness and effectiveness of financial institutions laws to proxy for law enforcement in the credit market. These measures capture banking and stock market reform, dimensions such as the power and authority of supervisors, money laundering issues, depositor protection, restrictions on foreign bank entry, etc. It may be argued that the financial institutions' effectiveness and the extensiveness capturing the regulator-bank relationship and stock market regulations are too general as they do not assess directly laws governing the lender-borrower relationship. As such, these indicators may not have any direct impact on a bank's decisions to lend. As shown, Slavova (1999) provides weak evidence on the role of law enforcement in credit market development. Similarly, Pistor, et al. (2000) use the RLI and the EBRD law effectiveness scores related to commercial laws and fail to provide strong evidence that law enforcement matters based on these measures if macroeconomic variables are included in the model.

Djankov, et al. (2007) measure the enforcement of creditor rights with the number of days it takes to enforce a simple debt contract (CED). This is the World Bank's so-called 'doing business' methodology using case study-based surveys originally developed by Djankov, et al. (2002). In their case study, law firms were asked for a complete write-up of the legal procedures necessary to dispute cases in court. Based on this, the measure is constructed by specifying the time it takes for courts to handle two types of cases: the eviction of a residential tenant for non-payment of rent and the collection of a cheque returned for non-payment. However, this measure is not without problems. First, while the case involving eviction of a residential tenant for non-payment of rent does not represent the operation of the commercial loans; the case involving the collection of a cheque returned for non-payment does capture the firm-trade creditor relationship worth 50 percent of country per capita GDP. Whether this captures the classical lender-borrower dispute is questionable. In particular, the amount of debt in the case study may not be appropriate - in the case of Kosovo this would be around $€ 900$, a typical consumer loan, which may not be an appropriate transaction for capturing the enforcement of creditor rights. Involving courts for resolving small transaction disputes may take too long and be more costly than the value of transaction itself since the courts may give priority to other disputes. For example, Messmann (2005) points out that court proceeding in civil matters are usually limited to high-value contracts and that small and medium contracts never reach courts for economic reasons. In addition, even if the case study could have involved a loan (the relationship between the lender and borrower instead of firm-trade creditor relationship), the small amount probably would not involve any collateral and the dispute would represent only a minor part of credit transactions (since credit transactions are in general secured, especially in transition economies).

Second, this measure may be inappropriate because, as Bonin and Schaffer (2002) point out, supplier-customer relationships are long-term in nature and suppliers are not likely to take customers to courts, especially when the amount is small. And third, regarding the case of the bounced cheque, it is worth noting that cheques may be rarely used as a means of payments, especially in less developed financial markets. Hence, the design of the case itself may not be representative. As mentioned, Djankov, et al. (2007) find that law enforcement matters for financial development. However, in separate regressions for developed and developing countries the significance of the law enforcement variable disappears for the sample of developing countries. Their comment on this result is that in 
developing countries information sharing institutions are substitutes for poor enforcement. However, it may be the case that their law enforcement variable is not representing the commercial reality in developing countries; hence, it is insignificant.

The need to concentrate on laws in practice in transition economies led the EBRD to embark on a New Legal Indicator Survey (hereinafter NLIS2003). By trying to capture commercial reality, the key concern of the survey was how effectively the process of enforcement of movable collateral works in practice. In this way the deficiencies of the LIS, which mainly dealt with law on secured transactions as it appears on books, were addressed. As described in EBRD (2003), for the law enforcement survey a case study methodology was adopted and an imaginary case was presented to commercial lawyers in transition economies (see http://www.ebrd.com for details on the methodology). They were asked to evaluate how the bank can enforce their rights in a case of borrower default. The evaluation had three dimensions: (i) how much of the loan the creditor can recover; (ii) how fast; and (iii) how simple is the recovery procedure. Each of these three criteria was assessed by lawyers and legal experts in each transition country. Using a scoring system of 0 (worst) to 10 (best), a maximum score (30) can be achieved if the loan is recovered in full amount, within one month and with clear, not complex and with simple enforcement procedures. In addition to the case study, 12 additional questions concerning the process of enforcement were asked to highlight the influence of third parties in this process. For example, within the process factors if the debtor can obstruct the process then that would have implications for the amount, time and simplicity dimensions in the enforcement process. The scoring for process and scope factors (being on a scale 1 to 3 ) is when 1 a minor, 2 a significant and 3 a major problem is encountered with a particular factor. As opposed to the amount, time and simplicity score, for the process and scope factors a higher score indicates greater level of complexity and hence a poorer performance. In addition, the EBRD in 2004 applied a similar case study methodology for assessing the enforcement of creditor and debtor initiated bankruptcy cases in terms of speed, efficiency and predictability (hereinafter NLIS2004).

As can be seen, there exist a variety of indicators that may proxy for institutional quality in general and law on books and enforcement in particular. Kaufmann and Kraay (2007) claim that inferences about institutional quality based on two data sources would be no more informative than inferences based on just one of them. This because the legal variables in general tend to correlate highly with each other and that correlation between creditor protection and financial development holds using virtually all the measures that proxy for the ability to contract (Munck and Verkuilen, 2002; Galindo and Micco, 2004). Given the ordinal character of law enforcement indices mentioned so far, Table 1 presents the Spearman rank-order correlation coefficients of several measures that proxy for the law enforcement and these indicate that these claims do not necessarily hold.

Table 1. Spearman rank-order correlation coefficients of law enforcement measures

\begin{tabular}{llllll}
\hline & CED & NLIS2003 & NLIS2004 & RLI & $\begin{array}{l}\text { LIS(Effectiveness } \\
\text { of Commercial } \begin{array}{l}\text { LIS (Effectiveness } \\
\text { of Financial } \\
\text { Regulation Laws) }\end{array}\end{array}$ \\
\hline CED & 1 & & & & \\
NLIS2003 & 0.0247 & 1 & & & \\
NLIS2004 & -0.1156 & -0.1549 & 1 & & \\
RLI & -0.0178 & $0.6805^{* * *}$ & $0.4388^{* *}$ & 1 & 1 \\
$\begin{array}{l}\text { LIS (Effectiveness of } \\
\text { Commercial Laws) }\end{array}$ & 0.0271 & $0.4412^{* *}$ & 0.2217 & $0.6466^{* * *}$ & 1 \\
$\begin{array}{l}\text { LIS (Effectiveness of } \\
\text { Financial Regulation Laws) }\end{array}$ & -0.1071 & $0.6597^{* * *}$ & 0.2114 & $0.7899^{* * *}$ & $0.7841^{* * *}$ \\
\hline
\end{tabular}

Notes: $* * *, * * *$ denote significance at $1 \%, 5 \%$ and $10 \%$, respectively.NLIS2003 is the enforcement of secured transactions laws from EBRD's 2003 survey; NLIS2004 is the enforcement of bankruptcy laws from EBRD's 2004 survey; CED is the number of days required to enforce a contract (the eviction of a residential tenant for non-payment of rent and the collection of a cheque returned for nonpayment); RLI is the rule of law index; LIS is the Legal Indicator Survey. 
As can be observed from the table, CED is not correlated with any of the other measures that proxy for law enforcement. Similarly, the NLIS2003 is not significantly correlated with NLIS2004. Hence, these measures appear to be picking up different dimensions of law enforcement that are uncorrelated with each other. However, other measures such as the RLI are significantly correlated with almost all the measures of law enforcement. As Pistor (2001) points out, the correlation among legal variables may suggest that they indeed are picking up something important, but we do not know exactly what. The level of correlation still suggests that these different measures are showing independent variation and may be in part proxying different aspects. The NLIS2003 and NLIS2004 specifically consider the lender-borrower relationship in dispute resolution and as such, more closely approximate the reality that would directly shape the creditors' expectations on how the law works in practice. As a result, in the empirical study in the next section the new EBRD measures of enforcement of collateral and bankruptcy laws are utilized which may be, at least in transition context, more appropriate measures.

\section{Creditor Rights And Financial Development in Transition Economies: Empirical Evidence}

In this section, the role of law enforcement in the credit market is empirically assessed in a cross-section of 25 transition countries by a thorough investigation of the alternative dimensions of financial development. The study uses a similar approach to Slavova (1999) and Pistor, et al. (2000) in terms of the cross-sectional analysis employed and in the context of investigation, i.e. transition countries. However, this analysis differs from existing literature on transition in many respects. First, the period under review is after 1999, when many adjustments in general environment had already taken place and macroeconomic stability had been restored in most transition economies. Second, the previous literature is extended by employing a broader set of dependent variables measuring financial development. The better protection of creditor rights will make ex ante credible the threat seizing collateral in the case of borrower default. This increases borrower incentives to perform in the interim, and as a result, banks are more willing to lend and volume of credit would be higher. However, this is only part of the story. There is no single measure that can cover fully the degree of financial development although most of the literature employs volume of credit to private sector to GDP. This measure covers both lending to the corporate and household sectors. Since the basis for lending are different for households and repayment rates may be higher than for corporate loans, particularly in the transition economies where the consumer loans dominate household credit, these loans may be less prone to legal disputes. As such, law enforcement may not have decisive impact on household lending.

Law enforcement may have also an impact in another important aspect of financial development, which is the quality of bank loan portfolios (non-performing loans). If better enforcement makes the default more costly ex ante, then borrowers may increase their effort on the project (decrease moral hazard) since they have more to lose in the case of default which would lead to lower NPLs. The banks' portfolios may worsen since the incentives of banks to screen are diminished when creditor rights are strongly enforced (Manove et al., 2001), or by opening up the market to borrowers with little collateral, poorer projects may enter the market (Jappelli et al., 2005). Terms of lending are another significant manifestation of financial development. The low quality of legal institutions in dispute resolution may involve high transaction costs due to lengthy and complicated procedures. These costs are borne by the lenders since, given low enforcement of collateral laws, recovery value may be low. Lenders may compensate for this by charging ex ante higher interest rates to cover these costs. Therefore, apart from the availability of credit, law enforcement may determine costs at which credit is available. Given that the unpredictability of the performance of legal institutions increases uncertainty, this shortens the horizon of transacting, i.e. debt contracts will be of shorter maturities. As mentioned, several studies found a positive impact of the legal aspects on the debt maturity as well as firm leverage (Demirgüc-Kunt and Maximovic, 1998; Hall and Jörgensen, 2005). Whether law variables influence debt maturity and firm leverage would cover additional dimensions of financial development.

Third, the channels through which the legal framework influences lending are also investigated. Haselmann, et al. (2006) claim that not all legal aspects are equally effective and the introduction of a legal regime that enhances each lender's prospects of enforcing their claims through collateral laws may result in a greater increase in lending than changes in bankruptcy law - the essence of which is to provide an orderly liquidation or reorganization in the presence of multiple creditors. Unlike Haselmann, et al. (2006) who consider the effect of bankruptcy and collateral laws as they appear on books, the existing literature is extended by considering if the enforcement of particular laws have a different influence on financial development. While the bankruptcy procedure cancels debt collection, e.g. stops premature liquidation and seeks appropriate treatment of distressed borrowers, secured lending facilitates debt collection. As such, the latter may be the preferred method in solving credit disputes and may be used more frequently 
in transition economies. Furthermore, recovery rates in bankruptcy tend to be low and time consuming even in developed market economies (Baird and Morrison, 2005; Djankov et al., 2006). Claessens and Klapper (2002) find that transition economies have lower use of bankruptcy laws since these are new laws and lenders and borrowers had no experience with them. They point out that firms in bank-based systems tend to have close relationships with their banks and have less distributed creditors; therefore they are less inclined to use the costly bankruptcy process. In addition, the authors point out that the larger the share of small firms in the economy the smaller the number of bankruptcies, since small firms are less likely to incur the cost of formal bankruptcy procedures

Fourth, the previous literature is extended by employing a measure of law enforcement which is specifically related to the bank-borrower relationship (enforcement of secured transactions and bankruptcy laws) and directly influences creditor expectations and their willingness to lend. As considered earlier, the new EBRD law enforcement measures (NLIS2003 and NLIS2004) are based on an improved methodology through case study which is likely to approximate closer with practice and capture the bank-borrower relationship more directly. In addition, other law enforcement measures such as CED and RLI are utilized for comparison. Apart from the usual macroeconomic controls that are employed in this framework (e.g. inflation, budget deficit), as mentioned, Djankov, et al. (2007) emphasize the role of credit registers in the credit market. By revealing some of the characteristics of borrowers through the credit register, lenders may predict more accurately loan defaults, reduce some of the cost of screening and they may engage in screening other characteristics of the borrower. This improves information availability, may reduce risk and the costs of external finance. Pagano and Jappelli (1993) argue that the impact of credit sharing institutions on lending volume may be ambiguous since the increase in lending to safe borrowers may fail to compensate for an eventual reduction in lending to risky types. Finally, the Djankov, et al. (2007) approach of assessing the presence/absence of credit registers is extended by examining the quality of registers as having an impact on the credit market development. The general model is as follows:

$$
\mathrm{Y}_{\mathrm{i}}=\alpha+\beta \mathrm{X}_{1 \mathrm{i}}+\gamma \mathrm{X}_{2 \mathrm{i}}+\varepsilon_{\mathrm{i}}
$$

where $\mathrm{Yi}$ is financial sector development measures, $\mathrm{X}_{1}$ is the vector of variables measuring the creditor rights as they appear on books and law enforcement, $X_{2}$ is the vector of control variables, $\alpha, \beta, \gamma$ are parameters to be estimated and $\varepsilon i$ is the random error. The full definition of dependent and explanatory variables is given in Appendix A while the regression results are presented in Table 2 . The regressions presented are statistically well specified and in the first specification the estimates indicate that law enforcement, specifically the new EBRD measure of enforcement of charged assets (NLIS2003), has a positive effect on the volume of bank credit to the private sector (PRIVCRED), which is statistically significant at the one percent level. The estimated impact is also economically significant, as an increase in the NLIS2003 indicator by one (where the standard deviation is 7.44) leads to an estimated one percentage point increase in PRIVCRED, on average. The new EBRD measure of enforcement of bankruptcy laws (NLIS2004) does not have a statistically significant impact on private credit (although it does have a positive sign) suggesting that bankruptcy law is less used in credit transactions and, as such, may not have decisive impact on the lending relationships. This finding is also in line with previous assertions and the finding of Haselmann, et al. (2006); however, their analysis has concentrated on law on books rather than enforcement of bankruptcy laws. The LAWONBOOK variable has no statistically significant impact on private credit. This is in line with the expectation that, in the transition context, the enforcement of laws may be of paramount importance rather than law itself, given that most transition economies have reformed their legal frameworks but their enforcement remained weak. Of the macroeconomic controls only inflation is statistically different from zero at five percent level (and is negative as expected). Higher inflation is associated with a narrower credit market and this may suggest that macroeconomic instability matters and may have detrimental effect on the financial sector development. 
Table 2. OLS estimation on financial development indicators in transition economies

\begin{tabular}{|c|c|c|c|c|c|c|c|}
\hline & PRIVCRED & CREDFIRMS & CREDHOUSE & NPL & INTEREST & MATURITY & LEVERAGE \\
\hline & (1) & (2) & (3) & (4) & (5) & (6) & (7) \\
\hline \multirow[t]{2}{*}{ NLIS2003 } & $1.026^{* * *}$ & $0.924^{* * *}$ & 0.014 & -0.226 & $-0.032 * * *$ & 0.249 & $0.401^{* *}$ \\
\hline & $(0.387)$ & $(0.260)$ & $(0.030)$ & $(0.210)$ & $(0.011)$ & $(0.273)$ & $(0.172)$ \\
\hline \multirow[t]{2}{*}{ NLIS2004 } & 0.075 & 0.106 & -0.003 & -0.025 & 0.005 & 0.227 & 0.038 \\
\hline & $(0.229)$ & $(0.154)$ & $(0.017)$ & $(0.123)$ & $(0.006)$ & $(0.162)$ & $(0.101)$ \\
\hline \multirow[t]{2}{*}{ LAWONBOOK } & -2.022 & -0.928 & -0.132 & -0.901 & 0.044 & 1.617 & 0.505 \\
\hline & (1.674) & (1.125) & $(0.130)$ & $(0.906)$ & $(0.048)$ & $(1.181)$ & $(0.741)$ \\
\hline \multirow[t]{2}{*}{ CREDITINFO } & 0.293 & -0.565 & $0.267^{* *}$ & -0.273 & $-0.152 * * *$ & $2.213^{* *}$ & -0.759 \\
\hline & $(1.478)$ & $(1.000)$ & $(0.116)$ & $(0.839)$ & $(0.043)$ & (1.049) & $(0.658)$ \\
\hline \multirow[t]{2}{*}{ INFLATION } & $-0.242 * *$ & $-0.156^{*}$ & -0.010 & -0.017 & $0.011 * * *$ & $-0.182 * *$ & -0.058 \\
\hline & $(0.120)$ & $(0.080)$ & $(0.009)$ & $(0.065)$ & $(0.003)$ & $(0.085)$ & $(0.053)$ \\
\hline \multirow[t]{2}{*}{ DEFICIT } & -0.887 & -1.167 & 0.002 & 0.409 & 0.008 & 0.931 & $1.083^{*}$ \\
\hline & (1.219) & $(0.820)$ & $(0.095)$ & $(0.702)$ & $(0.035)$ & $(0.860)$ & $(0.540)$ \\
\hline \multirow[t]{2}{*}{ GDPGROW } & -0.687 & -0.343 & -0.033 & $-1.403 * *$ & -0.040 & -0.030 & -0.710 \\
\hline & (1.066) & $(0.717)$ & $(0.083)$ & $(0.588)$ & $(0.030)$ & $(0.753)$ & $(0.472)$ \\
\hline \multirow[t]{2}{*}{ CONSTANT } & 17.71 & 4.45 & 1.972 & $23.92 * *$ & $2.903 * * *$ & -6.225 & $15.43^{*}$ \\
\hline & $(20.15)$ & $(13.55)$ & $(1.573)$ & $(10.82)$ & $(0.583)$ & $(14.21)$ & $(8.920)$ \\
\hline \multicolumn{8}{|l|}{ No. of } \\
\hline Adjusted $\mathrm{R}^{2}$ & 0.31 & 0.38 & 0.22 & 0.63 & 0.65 & 0.48 & 0.50 \\
\hline
\end{tabular}

Notes: ***,**, $*$ denote significance at $1 \%, 5 \%, 10 \%$, respectively; standard errors in parenthesis; p-values in brackets; PRIVCRED is the ratio of bank credit to the private sector to GDP; CREDFIRMS is the ratio of bank credit to the corporate sector to GDP; CREDHOUSE is the ratio of bank credit to the household sector to GDP; NPL is non-performing loans; INTEREST is the interest rate on loans; DEBTMAT is the average debt maturity in firms in particular country (in months); LEVERAGE is the average leverage of firms in particular country measured as the ratio of debt to total assets; NLIS2003 is the enforcement of secured transactions laws from EBRD's 2003 survey; NLIS2004 is the enforcement of bankruptcy laws from EBRD's 2004 survey; LAWONBOOK is law on books; CREDITINFO is credit information index; INFLATION is average yearly rate of inflation (in percentages); DEFICIT is average yearly government deficit to GDP (in percentages); GDPGROW is average yearly growth rate of GDP (in percentages).

In the second specification that captures volume of bank credit to the enterprise sector (CREDFIRMS), NLIS2003 has a positive effect which is significant statistically and economically. Other variables are insignificant except INFLATION which is negative and statistically significant. In this specification, CREDITINFO is insignificant and 
this may support the Pagano and Jappelli (1993) assertion that the impact of credit sharing institutions on lending volume may be ambiguous since the increase in lending to safe borrowers may fail to compensate for an eventual reduction in lending to risky types. Interestingly, in the estimation of bank credit to households (CREDHOUSE) NLIS2003 is not significant, while CREDINFO is positive and statistically significant at five percent level. This may support the view that basis of lending is different for households which are less prone to legal disputes, hence banks rely less on law enforcement in this type of lending. The lack of legal reform may also explain the 'household bias' in lending in transition economies, thus crowding out lending to the corporate sector. However, it should be noted that the case study in the EBRD2003 is designed specifically for commercial cases. As such, it may not be an appropriate proxy for legal disputes involving banks and households. The results also suggest that in lending to household sector information sharing institutions gain in importance, e.g. banks adopt a simpler screening technology for household loans and may rely on information provided by the credit registers.

The quality of the banking sector loan portfolio (NPL) is regressed on the same set of explanatory variables (specification 4). NLIS2003 is insignificant, although negative. The sign is in line with the view that the better the enforcement of creditor rights the lower the volume of bad loans in an economy (e.g. by making the default costly, it improves incentives to perform). GDPGROW is negative and significant at five percent level suggesting that in a declining (prospering) economy bad loans increase (decrease). The specification for lending rates (INTEREST) gives a negative and statistically significant effect of the enforcement of collateral laws (NLIS2003). This supports the hypothesis that, apart from the availability of credit, borrowers may have access to cheaper funds where the creditor rights are more protected, emphasizing the importance of law enforcement in the credit market. CREDITINFO is also negative and statistically significant supporting the previous claim that the better the creditors are informed ex ante on the borrower characteristics (i.e. the better the quality of credit registers) the better terms they are willing to provide. In specification 2, no evidence is found that the quality of credit registers increases the volume of bank lending to the corporate sector (e.g. increase in lending to safe firms may fail to compensate for an eventual reduction in lending to risky types). The evidence in specification 5 may be interpreted as the impact of information sharing institutions works through decreasing the costs of screening and these lower costs are reflected in lower interest rates. INFLATION, as expected, has a positive sign and is significant suggesting that higher inflation leads to higher interest rates, since banks compensate for the risk premium that the inflationary environment creates and/or compensate for the falling value of money.

In specification 6 which is concerned with debt maturity (MATURITY), NLIS2003 is positive (indicating a positive association between better law enforcement and access to longer-term credit), however it is statistically insignificant. The estimated effect of CREDITINFO is positive and is significant suggesting that when it comes to a longer period for the transactions the 'information hypothesis' appears to prevail. More specifically, for longer-term loans lenders may improve their screening or decisions may be based on established relationships with their clients and rely less on collateral. In this specification, INFLATION has a negative sign and is significantly different from zero at five percent level. As expected, this suggests that in inflationary environment lenders lend in shorter maturities. In specification 7 that regresses average firm leverage (LEVERAGE) NLIS2003 enters with positive sign and is statistically significant. In line with expectations, this suggests that better enforcement of law leads to higher firm leverage, on average. Other explanatory variables are statistically insignificant except DEFICIT, albeit significant at ten percent level.

In reviewing the previous literature the criticism was mainly focused on the measures of law enforcement, claiming that not all the measures of law enforcement reflect the reality in practice that shapes creditors' behaviour. As considered in section 2, it was hypothesized by some authors that correlation between creditor protection and financial development holds using virtually all the measures that proxy for the ability to contract. To further assess this, the same regression framework have been utilized, but with the preferred measures of law enforcement (NLIS2003 and NLIS2004) replaced with the CED variable and the RLI. The results for the two measures are presented in Table 3 . As can be observed, the CED does not have a significant impact on financial development (except in specification 4) and in most of the cases enters with incorrect sign. The RLI performs better since in most of the cases it has the expected sign and is significant, which is consistent with the regressions employing NLIS2003. Exceptions are the specification with LEVERAGE where RLI is insignificant, whereas NLIS2003 is significant; and the specification with MATURITY where RLI is significant while NLIS2003 is not. Therefore, the results seem very dependent on the choice of variables measuring law enforcement and different proxies of law enforcement matter and not all of them may be good reflections of the underlying reality. If one was to employ the CED to assess the impact of law 
enforcement in financial markets in transition economies, it would indicate that law enforcement is irrelevant (as Djankov et al., 2007 conclude for developing countries).

Table 3. OLS estimation on financial development indicators using Contract Enforcement Days and Rule of Law Index

\begin{tabular}{|c|c|c|c|c|c|c|c|c|c|c|c|c|c|c|}
\hline & \multicolumn{2}{|c|}{ PRIVCRED } & \multicolumn{2}{|c|}{ CREDFIRMS } & \multicolumn{2}{|c|}{ CREDHOUSE } & \multicolumn{2}{|c|}{ NPL } & \multicolumn{2}{|c|}{ INTEREST } & \multicolumn{2}{|c|}{ MATURITY } & \multicolumn{2}{|c|}{ LEVERAGE } \\
\hline & \multicolumn{2}{|c|}{ (1) } & \multicolumn{2}{|c|}{ (2) } & \multicolumn{2}{|c|}{ (3) } & \multicolumn{2}{|c|}{ (4) } & \multicolumn{2}{|c|}{ (5) } & \multicolumn{2}{|c|}{ (6) } & \multicolumn{2}{|c|}{ (7) } \\
\hline CED & -0.003 & & 0.009 & & -0.004 & & $0.011^{* * *}$ & & 0.009 & & 0.002 & & 0.005 & \\
\hline \multirow{3}{*}{ RLI } & $(0.012)$ & & $(0.009)$ & & $(0.008)$ & & $(0.003)$ & & $(0.037)$ & & $(0.008)$ & & $(0.005)$ & \\
\hline & & $16.41^{* * *}$ & & $14.35^{* * *}$ & & 0.201 & & -1.647 & & $-0.296^{*}$ & & $5.953^{*}$ & & 2.767 \\
\hline & & $(4.644)$ & & $(2.990)$ & & $(0.398)$ & & $(2.792)$ & & $(0.170)$ & & (3.494) & & $(2.505)$ \\
\hline \multirow[t]{2}{*}{ LAWONBOOK } & -0.878 & 0.199 & 0.032 & 0.934 & -0.103 & -0.090 & -0.877 & -1.211 & -0.017 & -0.034 & 1.351 & 1.681 & 0.942 & 1.122 \\
\hline & $(1.711)$ & $(1.340)$ & $(1.281)$ & $(0.862)$ & $(0.113)$ & $(0.115)$ & $(0.524)$ & $(0.817)$ & $(0.052)$ & $(0.049)$ & (1.211) & (1.055) & $0.734)$ & $0.723)$ \\
\hline \multirow[t]{2}{*}{ CREDITINFO } & 1.908 & -2.288 & 0.973 & $-2.742^{* *}$ & $0.286^{* * *}$ & 0.235 & -0.266 & -0.269 & $-0.198^{* * *}$ & $-0.120^{*}$ & $2.866^{* * *}$ & 1.275 & -0.010 & -0.810 \\
\hline & (1.544) & $(1.668)$ & $(1.156)$ & $(1.085)$ & $(0.102)$ & $(0.144)$ & $(0.487)$ & $(1.024)$ & $(0.054)$ & $(0.062)$ & $(0.899)$ & $(1.313)$ & $(0.660)$ & $(0.909)$ \\
\hline \multirow[t]{2}{*}{ INFLATION } & $-0.244 * *$ & -0.011 & -0.158 & 0.042 & -0.010 & -0.007 & 0.002 & -0.042 & $0.010^{* *}$ & 0.006 & $-0.196 * * *$ & $-0.116^{*}$ & -0.059 & -0.020 \\
\hline & $(0.137)$ & $(0.123)$ & $(0.102)$ & $(0.079)$ & $(0.009)$ & $(0.011)$ & $(0.042)$ & $(0.076)$ & $(0.004)$ & $(0.004)$ & $(0.059)$ & $(0.062)$ & $(0.058)$ & $(0.067)$ \\
\hline \multirow[t]{2}{*}{ DEFICIT } & -0.565 & -1.253 & -0.867 & $-1.464 * *$ & 0.006 & -0.003 & 0.359 & 0.354 & 0.001 & 0.013 & 1.086 & 0.842 & $1.211^{*}$ & $1.095^{*}$ \\
\hline & (1.395) & $(1.099)$ & $(1.044)$ & $(0.703)$ & $(0.092)$ & $(0.094)$ & $(0.449)$ & $(0.696)$ & $(0.043)$ & $(0.040)$ & $(1.099)$ & $(1.107)$ & $(0.599)$ & $(0.589)$ \\
\hline \multirow[t]{2}{*}{ GDPGROWTH } & -1.552 & -1.128 & -0.980 & -0.743 & -0.045 & -0.040 & -0.237 & $-1.315^{* *}$ & -0.025 & -0.023 & -0.052 & -0.097 & $-0.993^{*}$ & $-0.930^{*}$ \\
\hline & $(1.368)$ & $(0.922)$ & (1.024) & $(0.594)$ & $(0.090)$ & $(0.079)$ & $(0.432)$ & $(0.577)$ & $(0.042)$ & $(0.033)$ & $(0.718)$ & $(0.528)$ & $(0.587)$ & $(0.497)$ \\
\hline \multirow[t]{2}{*}{ CONSTANT } & $36.08^{* *}$ & $38.04^{* * * *}$ & 21.54 & $25.30^{* * *}$ & $1.938^{*}$ & $1.966^{* *}$ & 4.525 & $19.79^{* * *}$ & $3.066^{* * *}$ & $2.891^{* * *}$ & 10.161 & 13.913 & $22.40^{* * *}$ & $22.80^{* * *}$ \\
\hline & (16.24) & $(9.861)$ & (12.16) & $(6.346)$ & (1.079) & $(0.845)$ & $(5.107)$ & $(6.129)$ & $(0.495)$ & $(0.362)$ & (12.34) & $(9.018)$ & $(6.975)$ & $(5.320)$ \\
\hline $\begin{array}{l}\text { No. of } \\
\text { observations }\end{array}$ & 25 & 25 & 25 & 25 & 25 & 25 & 25 & 25 & 25 & 25 & 25 & 25 & 25 & 25 \\
\hline Adjusted $\mathrm{R}^{2}$ & 0.09 & 0.46 & 0.02 & 0.55 & 0.25 & 0.26 & 0.84 & 0.63 & 0.49 & 0.56 & 0.44 & 0.51 & 0.37 & 0.41 \\
\hline
\end{tabular}

Notes: ***,**,* denote significance at $1 \%, 5 \%, 10 \%$, respectively; standard errors in parenthesis; $p$-values in brackets; PRIVCRED is the ratio of bank credit to the private sector to GDP; CREDFIRMS is the ratio of bank credit to the corporate sector to GDP; CREDHOUSE is the ratio of bank credit to the household sector to GDP; NPL is non-performing loans; INTEREST is the interest rate on loans; MATURITY is the average debt maturity in firms in particular country (in months); LEVERAGE is the average leverage of firms in particular country measured as the ratio of debt to total assets; CED is the number of days required to enforce a contract (the eviction of a residential tenant for non-payment of rent and the collection of a cheque returned for non-payment); RLI is the rule of law index; LAWONBOOK is law on books; CREDITINFO is credit information index; INFLATION is average yearly rate of inflation (in percentages); DEFICIT is average yearly government deficit to GDP (in percentages); GDPGROW is average yearly growth rate of GDP (in percentages). 


\section{Enforcement of Creditor Rights in Kosovo}

During the first decade of transition when other transition economies were in the process of implementing reforms and building new institutions supportive of the market economy, Kosovo only after the war in 1999 had to build institutions from scratch. The administrative capacity based on the previous experience was insufficient and inappropriate to deal with the needs of the emerging market economy. In the beginning only the pre-1989 laws of socialist Yugoslavia were in force. But gradually, under the joint administration of the United Nations Mission in Kosovo (UNMIK) and the Kosovo Government and with the help of international community, new laws largely based on the international practices were adopted. Kosovo has been a successful case study in economic institutions building (Demekas, et al., 2002) and a number of laws that govern and facilitate the functioning of financial system were promulgated since 1999. These laws include the Law on the Central Bank, Law on Business Organizations, then laws that explicitly regulate the lender-borrower relationship, strengthen creditor rights and facilitate the development of the financial sector such as Law on the Liquidation and Reorganization of Legal Persons in Bankruptcy, Law on Pledges and the Establishment of a Pledge Filing Office, Law on Mortgages and the Establishment of an Immovable Property Rights Register, Law on the Financial Reporting of Business Organizations, etc.

The World Bank (2004) evaluated the 'laws in action' in Kosovo and pointed out many deficiencies in court procedures and constraints in enforcing creditor rights. In addition, based on oral interviews with bankers in Kosovo, Zahler (2004) claims that courts and judges tend to favour borrowers vis a vis the lenders in disputes. The author also points to the poor functioning of legal institutions governing financial transactions. However, using the World Bank 'doing business' methodology, BCI (2005) paints a very favourable picture of contract enforcement in Kosovo. As described previously, this methodology measures law enforcement by the number of days it takes to enforce a simple debt contract.

As shown in Table 4, Kosovo compares well with the other transition economies when it comes to enforcing contracts. It outperforms all transition economies, on average, all countries in the region and surprisingly even OECD countries. However, using the World Bank 'governance' methodology in assessing law enforcement (Rule of Law Index, also shown in Table 4) leads to opposite results. Kosovo seems to have the worst score compared to the countries in the region and is poorer than the CIS and CEE countries, on average. Of course, as mentioned previously these indicators have their drawbacks either because they may fail to fully capture the context of the lender-borrower relationship or are multidimensional. From the methodological point of view, the EBRD's approach (e.g. NLIS2003) enhanced the assessment of the legal aspects of financial development in transition, especially law enforcement that directly concerns the bank-borrower relationship. Given that the EBRD methodology has not been applied in Kosovo, an extended version of its approach has been implemented in the context of this research. 
Table 4. Rule of Law Index and Contract Enforcement in Kosovo (2005)

\begin{tabular}{lcc}
\hline & Contract Enforcement Days $^{\mathrm{a})}$ & Rule of Law Index $^{\mathrm{b})}$ \\
\hline Kosovo & 153 & -0.97 \\
Albania & 390 & -0.8 \\
Bosnia and Herzegovina & 330 & -0.62 \\
Bulgaria & 440 & -0.17 \\
Croatia & 415 & 0.07 \\
Romania & 335 & -0.22 \\
Macedonia & 509 & -0.34 \\
Serbia and Montenegro & 1028 & -0.63 \\
\hline SEE (average) & 492 & -0.46 \\
CEE (average) & 442 & 0.6 \\
CIS (average) & 331 & -0.85 \\
OECD (average) & 280 & 1.63 \\
\hline
\end{tabular}

Source: BCI (2005) and Kaufmann, et al. (2006).

Notes: a) Contract enforcement days is the number of days it takes to enforce a simple debt contract (the eviction of a residential tenant for non-payment of rent and the collection of a cheque returned for non-payment); b) The rule of law index is measured based on various aspects of the quality of institutions and reflects, among others, civil liberties, the freedom of press, political rights, crime, infrastructure, enforceability of government and private contracts, speediness and fairness of judicial process. It ranges from 2.5 to 2.5 and a higher score corresponds to better law enforcement.

\section{The Lender-Borrower Litigation Process: An Empirical Study}

The EBRD analysis of the litigation process focuses on the final stage of litigation, i.e. how the collateral disputes are handled by courts. However, as Hendley (2001) points out, only a small proportion of disputes ever end up in court because either they are settled or the potential costs of proceeding outweigh the potential benefits. The litigation process can be thought as comprising several stages. For example, Cooter and Rubinfeld (1989) in their analysis of law recognize four stages of legal disputes: harm, assertion of legal claim, bargaining and trial. Similarly, Hendley (2001) recognizes several stages of dispute resolution. The first stage is the harm when the defendant fails to perform the obligation on time. The second stage is grievance or 'blaming' stage when the plaintiff notifies the defendant of its dissatisfaction (this can take a variety of forms such as a polite reminder or a threat). The third stage is the claiming stage, where threat proves unsuccessful. At this stage the plaintiff decides on a legal claim or drops out. The final stage is the collection phase, where the legal institutions attempt to resolve the dispute.In the analysis of the law on the lender-borrower dispute a similar logic is followed. In the context of the bank-client relationship, the process of dispute resolution can be thought of as a game with sequential solutions between the lender and the defaulting borrower. Each step influences the expectation of recovery on the lenders' side. First, the dispute can be solved by voluntary compliance, i.e. without the involvement of formal institutions. It may be that most cases are resolved in this manner because the threat of legal action by banks against a borrower in default may be sufficient. In this phase, a part of the debt will be recovered and it will take some time for the recovery to take place. The evolution of voluntary compliance may be linked to various possibilities. Agents may know ex ante that the law and institutions that support that law are in place. Or, they may have no knowledge of the law and simply abide contracts based on trust. Alternatively, agents may be reluctant to deal with the state's formal institutions, care about their reputation and/or calculate costs/benefits of defaulting. On the other hand banks may prefer not to use courts because they consider them to be slow and thus opt using other means.

It seems that motives for voluntary compliance of the law are diverse. If institutions make the threat of enforcement credible, then voluntary compliance may outweigh compulsory enforcement and reduce transaction costs. Cross 
(2002) notes that to the extent that the agents believe that the legal system works, the costs of enforcing rules are reduced enormously by the simple fact that the individuals will not disobey the rules or violate property rights, a standard assumption in legal theory. As Rapaczynski (1996, p.88) puts it:

This is the old Hobbesian problem: when most people obey the law, the government can enforce it effectively and (relatively) cheaply against the few individuals who break it. But when obedience breaks down on large enough scale, no authority is strong enough to police everyone.

Thus, looking at the formal part of dispute resolution is only one part of the story. Formal and informal resolution should not be seen as substitutes, rather they complement each other. Specifically, when formal resolutions are efficient, informal ones should be more pronounced. The issue of voluntary compliance is not explored by the EBRD since the methodology was designed exclusively to explore how legal institutions work.

Second, the bargaining phase can be thought of as another step before the dispute comes to formal resolution. Again some amount will be recovered and it will take some time before the recovery is made. The weakest party in the bargaining phase reveals the functioning of institutions, or at least the perception of how institutions function. If lenders are the weakest in this phase, i.e. ready to make concessions, then this may signal poor performance of institutions in the dispute resolution. Again, this issue has not been explored by EBRD. Third, when it comes to enforcement then two possibilities exist: (i) self-help, i.e. the lender repossesses the collateral by court order but not involving court officials (or police), or (ii) court involvement. If a majority of disputes are solved with self-help, again that reflects not so much on the effectiveness of the law explicitly. Instead, it may signal the credibility of institutions which would have important policy implications. Specifically, enforcement by the state would be necessary in only a few cases, especially in small societies, to make the threat credible and thus can be quite effective by involving low costs. Given this, in the case of Kosovo, the distinction between the voluntary compliance and court involvement are made clear in the survey conducted. In all these stages the issue of how much of, and how fast, the problem loans are recovered is assessed. Finally, the EBRD case study asks lawyers to respond to questions on how much and how fast the recovery is made, assuming there is a ready market for collateral. Again, whether market for collateral exists is of crucial importance in shaping the lenders' expectations on debt recovery. Unlike the EBRD, the existence of the market for collaterals will also be considered.

\section{NLIS 2003 and Extensions for Kosovo}

In the survey undertaken for this research, the original NLIS2003 questions were retained in order to generate comparable results with other transition economies. However, the questionnaire was extended to explore other steps of the litigation process not analyzed by the EBRD (the questionnaire is available upon request to the authors). It takes into account the issue of voluntary compliance on the borrower's side, the bargaining phase of dispute resolution, a clearer distinction between methods of enforcement (self-help and court involvement) and the existence of a market for collateral. The case study survey was conducted in the period 2005-2007. Toçi and Mustafa (2010) replicate the survey and not very different results are obtained, given that the institutional quality does not change rapidly. Unlike the EBRD that conducted the survey with one local law firm in each transition country, this survey covered several bank officials from the two largest banks in Kosovo, covering above 70 percent of the lending market (four loan officers and two officials from the legal departments). There were several reasons behind choosing both legal experts and loan officers instead of a law firm. First, choosing the latter would reveal information only about the final stage of dispute resolution. When it comes to voluntary compliance, the bargaining phase, self-help and the market for collateral, the legal departments at banks and loan officers are involved in all these stages of dispute resolution. However, the bank legal experts have no experience of voluntary compliance whereas loan officers are the first to know. And if the dispute reaches court involvement, loan officers too are part of the story. Second, it is also important to note that by conducting a survey of one law firm, as it is the case with the EBRD method, may not produce results that can be generalised as the sample may not be representative. Third, another reason that this approach may be considered an improvement is that practical experience of bank officials is more extensive. For example, banks have their own legal departments (as in the case here) and would not hire a law firm to deal with defaulting cases - as assumed in the EBRD case study. On the other hand, it is very unlikely that the distressed borrower would hire a law firm to defend its case.The crucial issue of the survey was how much of the loan the creditor can recover in various phases of the litigation process and the enforcement process in terms of value, how long the recovery process is likely to take and how simple is the entire process. In addition, the process and scope factors were identified. Regarding the 
scores, when answers were given in a range (e.g. it takes two to six months to enforce the claim), the average figure is recorded. Subsequently, the answers by all the respondents are averaged to produce a single score.

The survey results are presented in Table 5 and show that enforcement of secured transactions in Kosovo seems satisfactory. This is in conformity with BCI (2005) reported earlier. However, the picture here is not as outstanding as there, though it may be considered more realistic. Regarding the 'how much' question (amount), Kosovo scores 6 out of 10; that is, lenders may expect to recover around 60 percent of the loan with the pledged collateral. Regarding the 'how fast' question (time), Kosovo scores 8 out of 10; that is, lenders may expect to recover the pledged collateral within six months. For 'simplicity' of the entire process, the score was 5 (of three possible answers: 1, 5 and 10). The reason that 'simplicity' was not scored 10 (the best ranking) was because of the responses relating to the functioning of courts: the presence of inexperienced judges to deal with cases, the lack of specialised courts, etc. The overall score of the NLIS 2003 for Kosovo is 19.

In terms of the process and scope factors, the major problems were 'immovables' and 'receivables'. The score was 2.5 which would mean that the enforcement process involving immovables and receivables involves some difficulties and recovering the claims is not easy. The main complaints of respondents were that courts lack the expertise and resources to do their job. Therefore, the enforcement process would be facilitated if specific commercial courts or specialized judges were to deal with commercial disputes. According to Stanfield, et al. (2004), commercial cases have lower priority compared to criminal and other cases in Kosovo. In addition, the number of court judges in capital city Prishtina in 1989 was 35 (when it had 120,000 inhabitants), while in 2004 the number of judges was 26 (with an estimated 0.5 million inhabitants). Table 6 compares the results of the survey in Kosovo with results in other countries. Kosovo's overall score of 19 for the NLIS2003, is above the average score for SEE and CIS regions, but not the CEE. Considering the countries in the region, Bulgaria, Croatia and Macedonia are ahead but Kosovo is not far behind. Regarding the process and scope factors, Kosovo scores 1.71 which outperforms the CIS and SEE average and scores better than all the countries in the region except Macedonia and Romania.

Table 5. Enforcement of collateral laws in Kosovo (NLIS 2003)

\begin{tabular}{|c|c|c|c|c|c|c|c|}
\hline & Loan Officer 1 & Loan Officer 2 & Loan Officer 3 & Loan Officer 4 & $\begin{array}{c}\text { Legal } \\
\text { Department } 1\end{array}$ & $\begin{array}{c}\text { Legal } \\
\text { Department } 2\end{array}$ & Overall Score \\
\hline \multicolumn{8}{|l|}{ NLIS2003 } \\
\hline Amount ( $\%$ of loan recovery) & $70-80 \%$ & $50-70 \%$ & $60 \%$ & $50 \%$ & $50-60 \%$ & na & $6(60 \%)$ \\
\hline $\begin{array}{l}\text { Time (taken in the recovery } \\
\text { process) }\end{array}$ & 2 months & 3-12 months & 5 months & $3-4$ months & 5-10 months & $1-6$ months & 8 (6 months) \\
\hline Simplicity & 5 & 5 & 5 & 5 & 5 & 5 & 5 \\
\hline \multicolumn{8}{|l|}{ Process Factors } \\
\hline Debtor obstruction & 1 & 2 & 1 & 2 & 2 & 2 & 1.67 \\
\hline Preferential creditors & 1 & 1 & 1 & 1 & 1 & 1 & 1 \\
\hline Creditor control & 1 & 2 & 2 & 2 & 2 & 1 & 1.67 \\
\hline Practical experience & 1 & 1 & 1 & 1 & 1 & 1 & 1 \\
\hline Corruption & 1 & 3 & 2 & 2 & 2 & 3 & 2.17 \\
\hline Institutions & 2 & 2 & 2 & 2 & 3 & 2 & 2.17 \\
\hline \multicolumn{8}{|l|}{ Scope Factors } \\
\hline Scope of collateral & 2 & 1 & 2 & 2 & 3 & 2 & 2 \\
\hline Insolvency process & na & na & na & na & na & na & na \\
\hline Insolvency ranking & 1 & 1 & 1 & 1 & 1 & 1 & 1 \\
\hline Inventory & 1 & 1 & 1 & 1 & 2 & 1 & 1.17 \\
\hline Immovables & 2 & 3 & 3 & 3 & 2 & 2 & 2.5 \\
\hline Receivables & 3 & 2 & 2 & 3 & 2 & 3 & 2.5 \\
\hline
\end{tabular}

Notes: Amount represents the percentage of the loan that lenders may expect to recover and ranges from 0 to 10 with higher scores corresponding to higher amounts of recovery; Time represents the time needed expressed in months that lenders may expect to recover a loan and ranges from 0 to 10 with higher scores corresponding to faster recovery; Simplicity represents how simple is the recovery process and takes value of 1,5 and 10 when the process involves major, moderate and minor complexities. Process and Scope factors take value of 1, 2 and 3 when the particular factor represents a minor, moderate and major problem in the enforcement process, respectively. 
Table 6. Enforcement of Secured Transactions in Kosovo

\begin{tabular}{lcc}
\hline & Amount, Time and Simplicity & Process and Scope Factors \\
\hline Kosovo & 19 & 1.71 \\
Albania & 18 & 1.92 \\
Bosnia and Herzegovina & 4 & 2.58 \\
Bulgaria & 23 & 1.83 \\
Croatia & 22 & 1.83 \\
Macedonia & 21 & 1.58 \\
Romania & 18 & 1.67 \\
Serbia and Montenegro & 19 & 2.17 \\
\hline SEE (average) & 17.9 & 1.94 \\
CEE (average) & 24.3 & 1.68 \\
CIS (average) & 13.2 & 2.18 \\
\hline Sorce: EBRD & & \\
\hline
\end{tabular}

Source: EBRD (2003) and own survey for Kosovo.

Notes: Amount, Time and Simplicity ranges from 0 to 30 and a higher score corresponds to better enforcement; Process and Scope factors take value of 1, 2 and 3 when the particular factor represents a minor, moderate and major problem in the enforcement process, respectively.

As mentioned, the present research extends the EBRD survey to capture other stages and elements prior to legal enforcement such as voluntary compliance, bargaining, self-help and the market for collateral. As can be observed from Table 7, the survey results reveal that more than 60 percent of defaulted loans never reach the court stage and are resolved by voluntary compliance, after the 'threat' is made. In these cases the recovery is almost 70 percent of the amount and interestingly, these cases are resolved within a period of two months. From the threats used by banks, respondents considered 'the bank will involve the court' as the most effective, followed by 'the bank will confiscate the collateral'. In the third place were reputation considerations such as 'the bank will not extend credit in the future', 'the bank will force the guarantor to pay the debt', etc. This may give an impression of the credibility of institutions in the country or at least in the lender-borrower relationship.

Table 7. Enforcement of collateral laws in Kosovo: extending the NLIS 2003

\begin{tabular}{|c|c|c|c|c|c|c|c|}
\hline & $\begin{array}{c}\text { Loan Officer } \\
1 \\
\end{array}$ & $\begin{array}{c}\text { Loan Officer } \\
2 \\
\end{array}$ & $\begin{array}{c}\text { Loan Officer } \\
3 \\
\end{array}$ & $\begin{array}{c}\text { Loan Officer } \\
4 \\
\end{array}$ & $\begin{array}{c}\text { Legal } \\
\text { Department } 1 \\
\end{array}$ & $\begin{array}{c}\text { Legal } \\
\text { Department } 2 \\
\end{array}$ & $\begin{array}{c}\text { Overall } \\
\text { Ranking }\end{array}$ \\
\hline \multicolumn{8}{|c|}{ Voluntary Compliance } \\
\hline$\%$ of cases & $70 \%$ & $70 \%$ & $60-70 \%$ & $50 \%$ & na & na & $63.75 \%$ \\
\hline Amount & $70-100 \%$ & $70 \%$ & $80 \%$ & $25-50 \%$ & na & na & $68.13 \%$ \\
\hline Time & 1 month & $1-2$ months & 2-3 months & 3-4 months & na & na & 2.13 months \\
\hline \multicolumn{8}{|l|}{ Bargaining } \\
\hline$\%$ of cases & $20-25 \%$ & $15 \%$ & $10 \%$ & $25 \%$ & $20 \%$ & $25 \%$ & $19.60 \%$ \\
\hline Amount & $90-100 \%$ & $70 \%$ & $80 \%$ & $75 \%$ & $50 \%$ & $70 \%$ & $73.33 \%$ \\
\hline Time & 1 month & $1-2$ months & 2 months & $1-2$ months & 3 months & 3 months & 2 months \\
\hline \multicolumn{8}{|l|}{ Self-help } \\
\hline$\%$ of cases & $70 \%$ & $50 \%$ & $50-60 \%$ & $50 \%$ & $10-15 \%$ & $50 \%$ & $47.92 \%$ \\
\hline Amount & $80 \%$ & $90 \%$ & $70 \%$ & $25-50 \%$ & $50-75 \%$ & $25-50 \%$ & $62.92 \%$ \\
\hline Time & $1-2$ months & $1-2$ months & 2-3 months & 3-4 months & 3 months & 2 months & 2.33 months \\
\hline \multicolumn{8}{|c|}{ Market for Collateral } \\
\hline$\%$ of cases & $25-50 \%$ & $25-50 \%$ & $25-50 \%$ & $25-50 \%$ & $80 \%$ & $20 \%$ & $41.67 \%$ \\
\hline Amount & $50-75 \%$ & $25-50 \%$ & $25-50 \%$ & $25-50 \%$ & $80-90 \%$ & $25 \%$ & $47.50 \%$ \\
\hline Time & $1-2$ months & 3-6 months & 3-4 months & 3-12 months & $2-5$ months & 3 months & 3.92 months \\
\hline
\end{tabular}


When 'threats' fail, the bargaining phase follows, though it is rarely practiced (less than 20 percent of cases). If bargaining takes place between the lenders and the defaulting borrower, they are not likely to give significant concessions. For example, they may extend the period of repayment but not other terms. Again, recovery in these cases is high (above 70 percent of the amount) and relatively short (within two months). This may show the better bargaining position of the banks and, again, the credibility of institutions. After the bargaining phase, there are two possibilities: self-help or court involvement. In terms of self-help, i.e. banks confiscating the collateral by court order but without the involvement of court officials and/or police, the results suggest that almost 50 percent of cases are solved in this way, over 60 percent of the amount is recovered and within two months. It is important to note that in all stages, the recovery is faster than with court involvement. When it comes to the existence of a market for collateral, the picture is somewhat different. Only 41 percent of the assets pledged have a ready market - the underlying assumption in the EBRD's NLIS 2003 - and the recovery is around 47 percent of the amount of loan and within a period of four months.

It seems that the bulk of disputes (above 60 percent) are resolved by voluntary compliance. Of the remainder, some 20 percent are resolved in the bargaining phase. In 50 percent of cases where the collateral is seized, it is done by banks themselves. Hence, only in a small proportion of cases does the dispute ends up in courts. This is not to say that enforcement does not matter. On the contrary, it should be in place and credible, otherwise it increases the culture of non-payment. This is also in line with some evidence for Kosovo suggesting that upon default, if borrowers need more time banks normally allow them one to two weeks extension but if the court is involved, its very presence makes the matter more serious and usually during the course of this process the borrower comes up with the money and pays (Stanfield et al., 2004). The credibility of enforcement will decrease the adverse incentives in the credit market and reduce the reliance on the courts which decreases the transaction costs compared to when courts are used.

Another important element is the extent to which creditors pursue their claims actively by demanding legal services. In the early years of transition when soft budget constraints were present, creditors did not pursue their bad claims actively, knowing that in the case of distress the government will provide rescue. Assessing law enforcement in Russian enterprises, Hendley, et al. (2001) find that the institutional environment rewards enterprises that pay attention to the legal side of their operations. Better law enforcement occurs when the legal staff work extensively on contractual matters and when enterprise personnel possess larger amounts of legal human capital. For the case of Kosovo, KCBS (2005) points out that one bank aggressively enforces its legal repossession and the right to sell the collateral with the help of its own legal staff who work closely with judges, sometimes 'showing them how', and is quite successful. Overall, the institutional setting for the enforcement of creditor rights in Kosovo seems to be comparable with and, in some cases better, than countries in the region and other transition economies. Nevertheless, the country is lagging behind the advanced reformers in CEE who are now members of the EU, suggesting that the institutional reform is under way but still has a long way to go.

\section{Conclusions}

This paper explored the role of institutions in financial development. Transition economies in general have succeeded in reforming their laws on books, particularly regarding creditor rights. However, various indicators suggest that the SEE and CIS countries are lagging behind the advanced reformers in the CEE in enforcing these rights. The empirical work undertaken in this paper suggests that as long as laws on creditor protection are not enforced, credit markets will be narrower, external finance will be available on a shorter-term and will be more expensive even if creditor rights are protected by law on books. Hence, the legal reform needs to be followed by the judicial reform, more specifically, improving the quality of enforcement mechanisms in dispute resolution for financial development to take-off.

By distinguishing the channels through which law enforcement facilitates financial development, evidence is provided that the main channel seems to be the enforcement of collateral laws rather than the bankruptcy law. This may well be because the collateral and bankruptcy laws serve different ends given that bankruptcy cancels debt collection while collateral law facilitates it. The evidence also suggests that law enforcement primarily affects credit to the corporate sector, rather than the household sector, presumably because the latter is less risky and less subject to legal proceedings. In addition, evidence is provided that systems of notice, i.e. the quality of credit registers, which improve information infrastructure in the credit market, and macroeconomic factors such as inflation matter for financial development, especially when this is indicated by the cost and maturity of external finance. 
The evidence presented indicates that different measures of law enforcement do not yield similar results when it comes to investigating the importance of law enforcement for financial development. Consequently, care should be taken on how the quality of institutions is measured and the context which it represents, given that the indicators measuring institutional quality have an impact on determining, among others, foreign direct investments. Measures relating to the general assessment of the quality of institutions, such as the RLI, have been criticized on the grounds that if they do not address the specific features of the legal system that can be modified, may not be useful for policy purposes (e.g. targeting specific laws and institutions responsible for their enforcement). Specific measures such as CED were criticized on the grounds that they may not indicate the underlying nature of credit transactions in a particular economy, hence, may be inappropriate.

It was only after the 1999 war that Kosovo started building new institutions of a market economy. Although Kosovo embarked on the transition process later, it compares well with other transition economies in terms of creditor rights. Notwithstanding that different methodologies may produce different outcomes, in terms of the enforcement of collateral laws the results presented in this paper suggest that the law works in Kosovo. By utilizing the NLIS2003 an improved method for assessing law enforcement - it is shown that, in terms of the enforcement of creditor rights in the banking sector, Kosovo compares well with countries in the region and other transition economies. By extending the NLIS2003 and investigating several steps in the litigation process, it is also shown that the bulk of default cases never go to court for dispute resolution but is resolved efficiently by voluntary compliance. This may suggest that the credibility of institutions plays a role. This is not to say that enforcement does not matter. On the contrary, enforcement or a threat of enforcement complements voluntary compliance by increasing the credibility of the system. The demonstration effect of enforcement institutions is of crucial importance, especially in small societies such as Kosovo, which are capable of building credibility and trust in the legal process. Credible enforcement in turn may encourage self-enforcing and voluntary compliance mechanisms. Given that court involvement has relatively higher transaction costs, more disputes will be resolved out of court, thus, economizing on those costs. On the other hand, provided that not many cases go to court, the investment necessary for strengthening the enforcement mechanisms is relatively small for the credibility to be assured - and this will have large positive implications for correcting adverse incentives in the credit market.

Acknowledgements: An earlier version of this paper was presented at $11^{\text {th }}$ Mediterranean Research Meeting, Florence and Montecatini Terme, Italy, 24-27 March 2010. The authors would like to thank Professor Jean Mangan for useful comments.

\section{References}

Arner, D., C. Booth, B. Hsu \& P. Lejot (2006). Property Rights, Collateral, Creditor Rights and Financial Development. European Business Law Review, 3, 1215 - 1240.

Baird, D. \& R. Morrison (2005). Serial Entrepreneurs and Small Business Bankruptcies. Columbia University, Law and Economics Working Paper, No. 265.

Beck, T., R. Levine \& N. Loayza (1999). Finance and the Sources of Growth. World Bank Working Paper, No. 2057.

Bester, H. (1985). Screening vs. Rationing in the Credit Market with Imperfect Information. American Economic Review, 75, 850 - 855.

Bester, H. (1987). The Role of Collateral in Credit Market with Imperfect Information. European Economic Review, $31,887-899$.

Bonin, J. \& M. Schaffer (2002). Revisiting Hungary's Bankruptcy Episode. in Meyendorff, A. and A. Thakor, eds.: Designing Financial Systems in Transition Economies: Strategies for Reform in Central and Eastern Europe, Cambridge MA: The MIT Press.

Business Conditions Index in Kosovo (2005). BCI, Prishtinë: Integra Consulting, KCBS and USAID.

Claessens, S. \& L. Klapper (2002). Bankruptcy around the World: Explanations of Its Relative Use. World Bank Working Paper, No. 2865.

Cooter, R. \& D. Rubinfeld (1989). Economic Analysis of Legal Disputes and Their Resolution. Journal of Economic Literature, 27, 1067 - 1097. 
Cross, F. (2002). Law and Economic Growth. Texas Law Review, 80, 1737 - 1759.

Davis, K. (2004). What Can the Rule of Law Variable Tell Us About Rule of Law Reform? New York University, Law and Economics Research Paper Series, No. 04-026.

Demirgüc-Kunt, A. \& D. Maximovic (1998). Law, Finance and Firm Growth. Journal of Finance, 53, 2107 - 2137.

DeSoto, H. (2000). The Mystery of Capital: Why Capitalism Triumphs in the West and Fails Everywhere Else, New York: Basic Books.

Djankov, S., C. McLiesh \& A. Shleifer (2007). Private Credit in 129 Countries. Journal of Financial Economics, 84, 299 - 329.

Djankov, S., R. LaPorta, F. Lopez-de-Silanes \& A. Shleifer (2002). Courts: The Lex Mundi Project, NBER Working Paper, No. 8890.

Djankov, S., O. Hart, C. McLiesh \& A. Shleifer (2006). Debt Enforcement around the World, NBER Working Paper, No. 12807.

European Bank for Reconstruction and Development, Transition Report, various years from 1995 to 2007, London: EBRD.

Galindo, A. \& A. Micco (2004). Creditor Protection and Financial Markets: Empirical Evidence and Implications for Latin America. Federal Reserve Bank of Atlanta Economic Review, 2, 29 - 37.

Goldsmith, R. (1969). Financial Structure and Development, New Haven: The Yale University Press.

Hall, T. \& F. Jörgensen (2005). Legal Variation and External Finance, presented at Emerging Markets Finance Conference, Cass Business School, London, U.K., May 5-6, 2005.

Haselmann, R., K. Pistor \& V. Vig (2006). How Law Affects Lending, MPRA Working Paper, No. 157.

Hendley, K. (2001). Beyond the Tip of the Iceberg: Business Disputes in Russia. in Murrell, P., ed.: Assessing the Value of Law in Transition Economies, Ann Arbor: The University of Michigan Press.

Hendley, K., P. Murrell \& R. Ryterman (2001). Law Works in Russia: The Role of Law in Interenterprise Transactions. in Murrell, P., ed.: Assessing the Value of Law in Transition Economies, Ann Arbor: The University of Michigan Press.

Jappelli, T., M. Pagano \& M. Bianco (2005). Courts and Banks: Effects of Judicial Enforcement on Credit Markets. Journal of Money, Credit, and Banking, 37, 223 - 244.

Kaufmann, D. \& A. Kraay (2007). Governance Indicators: Where Are We, Where Should We Be Going? World Bank Working Paper, No. 4370.

Kaufmann, D., A. Kraay \& M. Mastruzzi (2006). Governance Matters V: Governance Indicators for 1996-2005, World Bank Working Paper, No. 4012.

King, R. \& R. Levine (1993). Financial Intermediation and Economic Development. in Mayer, C. and X. Vives, eds.: Capital Markets and Financial Intermediation, London: CEPR.

Kosovo Cluster and Business Support Project (2005). Constraint Study, Prishtinë: KCBS.

LaPorta, R., F. Lopez-de-Silanes, A. Shleifer \& R. Vishny (1997). Legal Determinants of External Finance. Journal of Finance, 52, 1131 - 1150.

LaPorta, R., F. Lopez-de-Silanes, A. Shleifer \& R.Vishny (1998). Law and Finance. Journal of Political Economy, $106,1113-1155$.

Levine, R. (1997). Financial Development and Economic Growth: Views and Agenda. Journal of Economic Literature, 35, 688 - 726.

Levine, R., N. Loayza \& T. Beck (2000). Financial Intermediation and Growth: Causality and Causes. Journal of Monetary Economics, 46, 31 - 77. 
Manove, M., A. Padilla \& M. Pagano (2001). Collateral versus Project Screening: A Model of Lazy Banks. RAND Journal of Economics, 32, 726 - 744.

Messmann, S. (2005). Enforcement of Contracts in Central and Eastern Europe: A General Survey. in Andenas, M. and G. Sanders, eds.: Enforcing Contracts in Transition Economies, London: The British Institute of International and Comparative Law.

Munck, G. \& J. Verkuilen (2002). Conceptualizing and Measuring Democracy: Evaluating Alternative Indices. Comparative Political Studies, 35, 5 - 34.

Pagano, M. \& T. Jappelli (1993). Information Sharing in Credit Markets. Journal of Finance, 43, 1693 - 1718.

Pistor, K. (2000). Patterns of Legal Change: Shareholder and Creditor Rights in Transition Economies. EBRD Working Paper, No. 49.

Pistor, K. (2001). Institutional Reform: Importing and Adapting Legal Systems, presented at EUDN Annual Global Development Conference: Understanding Reform, Rio de Janeiro, Brazil, December 11, 2001.

Pistor, K., M. Raiser \& S. Gelfer (2000). Law and Finance in Transition Economies. Economics of Transition, 8, 325 368.

Rapaczynski, A. (1996). The Roles of the State and the Market in Establishing Property Rights. Journal of Economic Perspectives, 10, 87 - 103.

Slavova, S. (1999). Law and Finance in Transition Economies, LSE Financial Markets Group, London School of Economics and Political Science Special Paper, No. 121.

Stanfield, D., S. Thomas, K. Kelm and J. Dorsey (2004). An Assessment of Property Rights in Kosovo, Prishtinë: USAID.

Stglitz, J. \& A. Weiss (1981). Credit Rationing in Markets with Imperfect Information. American Economic Review, $71,393-410$.

Toçi, V. \& A. Mustafa (2010). Enforcement of Creditor Rights in Kosovo. Financial Stability Report No.1, Central Bank of the Republic of Kosovo, Prishtina: CBK

World Bank (2004). Kosovo Economic Memorandum, Country Report, No. 28023-KOS.

Zahler, R. (2004). Financial Sector's Role in Economic Development in Kosova, Zahler\&Co., Santiago, Chile, mimeo.

Zingales, L. (2003). Commentary on: More on Finance and Growth - More Finance, More Growth? Federal Reserve Bank of St. Louis Review, 85, 47 - 52. 


\section{Appendix A. Definition of variables}

Variable

Definition

Source

\begin{tabular}{|c|c|c|}
\hline PRIVCRED & $\begin{array}{l}\text { The ratio of total outstanding bank credit to the private sector, including credit to } \\
\text { households and enterprises, to GDP. The data are as of } 2003 \text {. }\end{array}$ & EBRD, Transition Report, various issues \\
\hline CREDFIRMS & $\begin{array}{l}\text { The ratio of total outstanding bank credit to enterprises to GDP. The data are as of } \\
2003 \text {. }\end{array}$ & EBRD, Transition Report, various issues \\
\hline CREDHOUSE & $\begin{array}{l}\text { The ratio of total outstanding bank credit to households to GDP. The data are as of } \\
2003 \text { and are logged. }\end{array}$ & EBRD, Transition Report, various issues \\
\hline NPL & $\begin{array}{l}\text { Non-performing loans as a percentage of to total loans including sub-standard, } \\
\text { doubtful and loss classification categories. The data are as of } 2003 \text {. }\end{array}$ & EBRD, Transition Report, various issues \\
\hline INTEREST & $\begin{array}{l}\text { Lending rates are weighted averages across maturities and where not available rates } \\
\text { are quoted for the most frequently used instruments. The data are as of } 2003 \text { and } \\
\text { are logged. }\end{array}$ & $\begin{array}{l}\text { EBRD, Transition Report, various issues } \\
\text { and European Commission }(2004,2005)\end{array}$ \\
\hline MATURITY & $\begin{array}{l}\text { Average maturity of loans to firms in a particular country expressed in months. The } \\
\text { data are as of } 2002 \text {. }\end{array}$ & $\begin{array}{l}\text { The EBRD/World Bank Business } \\
\text { Environment and Entreprise Survey } \\
\text { (BEEPS 2002) }\end{array}$ \\
\hline LEVERAGE & $\begin{array}{l}\text { Average firm leverage (debt/total assets) in a particular country expressed in } \\
\text { percentages. The data are as of } 2002 .\end{array}$ & $\begin{array}{l}\text { The EBRD/World Bank Business } \\
\text { Environment and Entreprise Survey } \\
\text { (BEEPS, 2002) }\end{array}$ \\
\hline NLIS2003 & $\begin{array}{l}\text { The enforcement of secured transactions laws in TEs, as measured by the EBRD } \\
\text { survey through case study, in terms of amount, time and simplicity. The scores take } \\
\text { values ranging from } 0 \text { to } 30 \text {. Higher the score, the better enforcement of the } \\
\text { particular law is practiced in a country. }\end{array}$ & EBRD (2003) \\
\hline NLIS2004 & $\begin{array}{l}\text { The EBRD measure of the enforcement of creditor initiated bankruptcy cases in } \\
\text { TEs and the scores take values ranging from } 0 \text { to } 100 \text {. Higher the score, the better } \\
\text { enforcement of the particular law is practiced in a country. }\end{array}$ & EBRD (2004) \\
\hline CED & $\begin{array}{l}\text { The indicator measures the time of dispute resolution - in calendar days - counted } \\
\text { from the moment the plaintiff files the lawsuit in court until settlement or payment. } \\
\text { This includes both the days where actions take place and waiting periods between } \\
\text { actions. The data are as of } 2003 \text {. }\end{array}$ & World Bank, Doing Businnes \\
\hline RLI & $\begin{array}{l}\text { The Rule of Law Index combines several indicators that measure the extent to } \\
\text { which agents have confidence in and abide by the rules of society. These include, } \\
\text { among others, perceptions of the incidence of both violent and non-violent crime, } \\
\text { the effectiveness and predictability of the judiciary, and the enforceability of } \\
\text { contracts. Together, these indicators measure the success of a society in developing } \\
\text { an environment in which fair and predictable rules form the basis for economic and } \\
\text { social interactions. The variable ranges from }-2.5 \text { to } 2.5 \text {. A higher/positive value } \\
\text { indicate greater rule of law. The data are as of } 2003 \text {. }\end{array}$ & World Bank, Governance Indicators \\
\hline LAWONBOOK & $\begin{array}{l}\text { The index measures the degree to which collateral and bankruptcy laws facilitate } \\
\text { lending. It is based on data collected through research of collateral and insolvency } \\
\text { laws. It includes three aspects related to legal rights in bankruptcy, and seven } \\
\text { aspects found in collateral law. The index ranges from } 0 \text { to } 10 \text {, with higher scores } \\
\text { indicating that collateral and bankruptcy laws are better designed to expand access } \\
\text { to credit. The data are as of } 2003 \text {. }\end{array}$ & World Bank, Doing Businnes \\
\hline CREDITINFO & $\begin{array}{l}\text { This index measures rules affecting the scope, access and quality of credit } \\
\text { information available through either public or private bureaus. The index ranges } \\
\text { from } 0 \text { to } 6 \text {, with higher values indicating that more credit information is available } \\
\text { from either a public registry or a private bureau to facilitate lending decisions. The } \\
\text { data are as of } 2003 \text {. }\end{array}$ & World Bank, Doing Businnes \\
\hline INFLATION & Average yearly inflation over the period 1999-2003 expressed in percentages. & EBRD, Transition Report, various issues \\
\hline DEFICIT & $\begin{array}{l}\text { Average yearly government deficit to GDP ratio over the period 1999-2003 } \\
\text { expressed in percentages. }\end{array}$ & EBRD, Transition Report, various issues \\
\hline GDPGROW & GDP growth rates over the period $1999-2003$ expressed in percentages. & EBRD, Transition Report, various issues \\
\hline
\end{tabular}

